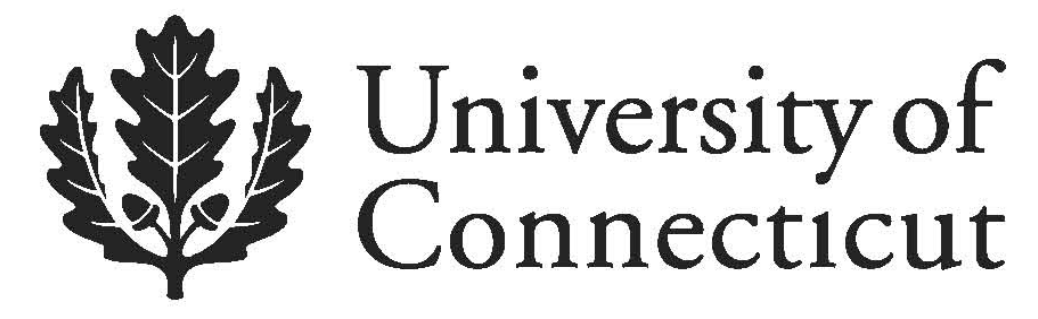

Department of Economics Working Paper Series

\title{
The Institutional Revolution: A Review Essay
}

Richard N. Langlois

University of Connecticut

Working Paper 2013-11

February 2013

365 Fairfield Way, Unit 1063

Storrs, CT 06269-1063

Phone: (860) 486-3022

Fax: (860) 486-4463

http://www.econ.uconn.edu/

This working paper is indexed on RePEc, http://repec.org 


\title{
The Institutional Revolution: A Review Essay
}

\author{
Richard N. Langlois \\ The University of Connecticut \\ Storrs, CT 06269-1063 USA \\ (860) 821-0152 (phone) \\ (860) 486-4463 (fax) \\ Richard.Langlois@UConn.edu
}

February 2013

\section{DRAFT}

Not for citation without author's consent 


\begin{abstract}
This review essay discusses and appraises Douglas Allen's The Institutional Revolution (2011) as a way of reflecting on the uses of the New Institutional Economics (NIE) in economic history. It praises and defends Allen's method of asking "what economic problem were these institutions solving?" But it insists that such comparativeinstitutional analysis be imbedded within a deeper account of institutional change, one driven principally by changes - often endogenous changes - in the extent of the market and in relative scarcities. The essay supports its argument with a variety of examples of the NIE applied to economic history.
\end{abstract}

Journal of Economic Literature Classifications: B52, D02, D23, N01, N4

Keywords: institutions, transaction costs, aristocracy, military history, factory system. 
In the early modern period, British aristocrats engaged in a panoply of seemingly inefficient activities. They owned grandiose, isolated, high-maintenance estates, which they encumbered with entails that destroyed the market value of the holdings. They converted productive farmland into elaborate parks and gardens. They refused to engage directly in any commercial activity, and spent their hours cultivating demanding but seemingly useless skills like music, dancing, repartee, and Latin conjugations. They threw lavish parties and consumed conspicuously. Yet despite these apparently wealthdestroying behaviors, aristocrats grew wealthy, often astoundingly wealthy. This is a puzzle. As Douglas Allen asks in his marvelous book The Institutional Revolution, "what economic problem were they solving in order to generate this wealth?” (Allen 2011, p. $56)$.

This, I want to suggest, is exactly the right question. And the answers Allen gives to this and similar questions mark the book as a milestone in the New Institutional Economics (NIE). Rather than labeling puzzling behaviors as ignorant and inefficient (as historians once tended to do) or as mechanisms for oppressing the lower classes (as cultural historians nowadays tend almost unanimously to do), the NIE attempts to explain such puzzles as responses to the costs, constraints, and scarcities the economic actors faced. This is the method of comparative-institutional analysis, inspired by Coase (1937, 1960), pioneered by Demsetz (1969), and championed by Williamson (1991). Rather than comparing actual (maybe puzzling) behavior against some imaginary frictionless standard, the NIE insists on comparing plausible institutional systems in real-world contexts rich in transaction (and other) costs. Explanation here consists in arguing that, and in detailing precisely how, the institutional system we observe is actually confronting 
some specified economic problem better than alternative candidates would have done. The hard part- the creative part - lies in discovering or imagining the right economic problem. What economic problem were they solving?

In Allen's case, the problem is variance. In the early modern period, Europeans had far less control over the vagaries of nature than they would come to have in more recent times. There were no reliable clocks. Transportation moved on the whims of wind and weather, and of pirates and highwaymen. One's contracting partners died early and often, from smallpox and other dangers about which we've forgotten. Such a world is full of unique local instances, and little, relatively speaking, is predictable and standardized. Thus it was hard for a principal to discern whether an agent's behavior was the result of the agent's own actions or of random exogenous factors. This limited the efficacy of the simple incentive systems typical in markets, especially in the area of Allen's central focus, public services, which even today we normally discuss in terms of special transaction-cost problems. Along with generally high transportation and communication costs, variance also limits the reach of direct monitoring through bureaucracy.

How then did Europeans (especially Britons) organize public services effectively in such a world? Implicitly, Allen compares three institutional systems: residual-claim arrangements (venal offices), patron-trust networks, and bureaucracies. His central argument is that, because of high variance, early modern Europe relied on venal offices and patron-trust networks to provide its public services. Modern-style bureaucracy, which relies on direct monitoring, became efficient for public services only with the 
standardization, reduction of variance, and lower communications costs that followed the industrial revolution.

In this scheme, aristocracy was a classic patron-client network. Its job was to provide managerial and administrative services for the developing nation-states of earlymodern Europe. Because of the transaction costs of a high-variance world, Allen argues, it would have been costly to appoint and then monitor anonymous candidates based on merit. It was more effective to employ specially chosen candidates loyal to the appointing patron. The patron-client relationship became in effect a relational contract in which the principal would reward or punish the agent not for any specific action but for a longer-term pattern of actions - that is, for loyalty. The patron's personal knowledge of the client was a far more important criterion than the client's qualifications for the job, narrowly understood. Most interestingly, clients had an incentive to incur bonding expenses to demonstrate and insure their loyalty to potential patrons. Voilà the puzzling behavior of aristocrats. The seemingly inefficient outlays for real estate, human capital, and social capital were actually hostage investments: valuable if the client remained within aristocratic society (the pool of potential clients) but worthless if the client were to be ostracized for defecting from the relational contract. This model allows Allen to understand even the aristocratic practice of dueling, which moderns consider bizarre and inexplicable. Dueling, it turns out, is a mechanism for screening marginal entrants into the aristocracy - for sorting genuine cooperators from potential defectors. ${ }^{1}$

See Miller, Wagner, and Zeckhauser (2013) for a formal model in which offering a risky alternative sorts for higher-productivity individuals. 
The institution of venal offices partakes of a simpler logic: if it is hard to monitor the agent, then make the agent a residual claimant and so create an incentive for selfmonitoring. The holder of a venal office is largely autonomous, earning income from user fees and various sorts of bribes; he may even have to buy, or be able to sell, the office. This is of course the fundamental logic of property rights and markets familiar from Econ 101, even if it may jar when translated into the realm of services that public bureaucracies typically provide today. The residual-claimant approach works effectively when, as we assume in the basic market model, there are no significant externalities of the agent's behavior that fall on society at large or, perhaps more importantly, on some administrative principal. The early modern period dealt with the problem of externalities by employing venal offices only when the incentives those arrangements created lined up fairly well with the desires of the principal, as well as by embedding the offices in a larger patron-client network.

There is no better illustration of these two institutional systems in action than the British military in this period, the analysis of which is one of the striking contributions of Allen's book. The British Army used the system of venal offices. Until well into the $19^{\text {th }}$ Century, an army commission was basically a taxi medallion: one had to buy one's commission, and, except at the highest ranks, could sell the commission to others. Because officers were rewarded by the spoils of battle, a commission was a capital investment with a positive, often high, present value. Since that value depended in part on the abilities of the officer, candidates would tend to self-select for ability. And the residual claimant's incentives - to pursue the enemy to collect spoils - lined up closely enough with the military's desire to win battles. 
By contrast, naval officers did not buy and sell commissions. One became a naval officer by securing the patronage of a member of the aristocracy. This filter selected for candidates predisposed to loyalty. In addition, the officer's behavior was restricted by an elaborate set of rules, monitored by an equally elaborate system involving lower officers, and enforced by a set of harsh punishments. Why the difference? For Allen the answer is straightforward: differences in variance. Because ships were at the mercy of winds and often had to travel large distances without communication or good navigation systems, it was much harder for the admiralty to tell if an officer failed to perform intentionally or because of unavoidable external circumstances. Naval officers were also residual claimants of plunder, of course. But they had the alternative of soft - commercial targets, and thus an incentive to avoid military confrontations. ${ }^{2}$ Patron-client loyalty, rules, monitoring, and punishment all combined to ensure that, unlike captains in France and elsewhere, British officers unfailingly engaged the enemy and seldom ran from a fight. This generated a further incentive for captains to maintain high levels of training and discipline among the crew. The ultimate result was the most formidable and successful naval force of the early-modern period.

Before offering some (perhaps slightly critical) perspectives on Allen's work, I want to defend Allen from a potential criticism. I praised The Institutional Revolution as a solid and original contribution to the NIE because it asks "what economic problem were they solving?" Some critics would pounce on this characterization, seeing it not as the

2 One might argue that the availability of soft naval targets would have been enough to explain the differences in the two systems. But the army was also tempted by incidental (not battle-related) plunder, which was forbidden by rule. Allen argues that the lower variability of land fighting made it easier for the higher-ups to monitor the behavior of army officers directly. 
essence of good practice but as an example of all that is wrong with the NIE. By imagining alternative economic problems that observed institutions might be solving, these critics would say, one is creating a set of "just-so" stories: accounts that are sufficient but not necessary, that fit the facts but may not be the best, let alone the only, plausible story. The appropriate retort, I believe, is that good comparative-institutional analysis requires constant critical argument and analysis. One of the lessons of the philosophy of science, it seems to me, is that it is impossible to rule out theories on abstract methodological grounds. What defeats a weak theory is another, stronger theory. Comparative-institutional analysis depends and thrives on criticism and revision. I will mention below a couple of cases in which, I believe, the process of criticism and revision has refined, modified, and enriched institutional explanations that began (among economists) with a conjectured just-so story.

At the same time, I have long argued that it is important to place any just-so story in its proper temporal or historical context: to pay attention to how institutions change, not just to how they solve a static snapshot of an allocation problem (Langlois 1986). From a methodological point of view, one wants to engage institutional change because change helps focus us on the nature of the selection problem that inevitably sits behind every economic problem. In asking the "which problem?" question, we really also need to ask: "why did this institutional solution come to be and why does it persist?"

Allen calls the book The Institutional Revolution. A revolution is by definition about change, and Allen does in fact often seem to be trying to explain why institutions change. I imagine that he would insist that his agent of change is the degree of variance 
and (non)standardization. As variance increases or decreases, institutions change. My complaint with this explanation is not that it is monocausal (Allen 2011, p. xiii): I rather like parsimonious monocausal explanations. My complaint is that variance is too thin a monocausal explanation of institutional change. So thin, indeed, that it is not even the cause Allen himself implicitly invokes when he explains institutional change. My alternative? The extent of the market. ${ }^{3}$ Standardization is clearly one facet of the extent of the market, but it is not the whole of it. We can think of the extent of the market as a thick thread, of which standardization is but one strand. Standardization, technology, institutions, and the extent of the market coevolve; but they are not all the same thing. In this coevolutionary process, standardization can sometimes be causal. At other times, as I will show, standardization can be the result of institutional change, not the cause.

Why did the aristocratic trust-system of the early modern period supplant the system of administration through the royal household and the feudal system? "When Henry VIII was crowned in 1509, he was wealthier than William was in 1066, and his demand for administrative servants was correspondingly greater" (Allen 2011, p. 51). The greater extent of the market meant that the old system, which relied on direct monitoring of household servants and allegiances with feudal potentates, had to go. And why did the patron-trust system disappear in favor of bureaucracy and merit?

For England, the eighteenth century saw tremendous growth in its empire. By the end of this century, the colonies of British North America and India were not controlled by monopoly companies but rather were being

The conception of institutional change I am pushing here actually goes beyond just the effects of the extent of the market to include, as we will see, changes in relative prices more generally. It is essentially the original Northian account of institutional change (North 1981), as elaborated by Ruttan and Hayami (1984). I do not deny the cognitive dimension of institutions, which North stresses in his more recent work (North 2005). But for present purposes the extent of the market is all we need. 
administered by the British civil service. This change was part of an enormous growth in the civil service. Whereas in 1700 members may have numbered 1,000-2,000, by 1914 the British civil service had 167,628 employees, and by 1919 this number had grown to 393,205. Brewer [1988] states that in the seventeenth century, "the overall picture is clear: the central administrative apparatus was tiny." He estimates that in 1688 the civil service employment was 2,500 men and that by 1760 it had grown to 16,000. As time went on, these new positions were not filled by patronage but through examinations and interviews with selection boards. France, Germany, and other European countries obtained colonial empires in the nineteenth century with similar civil administrations, again appointed generally outside the realm of patronage. Likewise in the United States, the nineteenth century saw a decline in the role of patronage, culminating in the Pendleton Act of 1883. Johnson and Libecap [1994] document how the increase in the sheer size of the civil service over this period prevented the president or members of Congress from controlling and benefiting from their patronage appointments, and note that the federal workforce grew from 26,000 to 51,000 between 1851 and 1871. (Allen 2011, p. 104.)

Neither of these institutional revolutions - the transition to the aristocratic patron-trust system and the transition away from it - was driven at a fundamental level by exogenous changes in the degree of variability and standardization. This is so even though, perhaps especially in the latter case, increased standardization and declines in transportation and communications costs did attend the growth of the extent of the market. ${ }^{4}$

In many ways, what I am suggesting here is but a minor doctrinal shift within the canon of the NIE - away form a purely Coasean account to a more Northian one. Allen aligns himself with Coase from the start. Coase, he says,

showed that [rules] matter because of transaction costs and that the form of an institution only depends on this one type of cost. The crux of his watershed paper, therefore, was that laws (and other rules or property

4 Another important factor, as Allen (2011, p. 104) mentions, is that the bourgeois commercial economy had grown significantly in relation to the aristocratic sector, shifting the marginal career choice between commerce and aristocracy increasingly in the direction of the bourgeoisie. I return below to the importance of commerce for explaining British aristocracy. 
rights) were consciously designed by economic actors - here the Crown, aristocrats, and servants - to maximize wealth (the monetary value that implicitly or explicitly attaches to everything people value), minus the socalled transaction costs. Understanding the transaction costs of a given situation is necessary and sufficient for understanding the institutional structure of that situation. (Allen 2011, p. 19.)

It is not entirely clear to me what Allen means here by saying that only transaction costs matter and that understanding them is necessary and sufficient for understanding institutions. $^{5}$ If he means that, in our comparative-institutional analysis, we need consider only the extent to which alternative institutions minimize transaction costs, then, I'm afraid, he is making a mistake. In fact, we need to argue about which alternative institutional structure minimizes the sum of production costs and transaction costs, and we have to recognize that there can be tradeoffs between the two (North 2005, p. 15 n3; Williamson 1985, p. 22).

In North's account, transaction costs matter mightily. But institutional change is driven in the end by changes in relative prices, which may involve changes in production costs (resulting from changes in factor abundances, for example) as much as changes in transaction costs. ${ }^{6}$ Take for example North's analysis of serfdom (North 1981, pp. 129131). In Europe in the early Middle Ages, markets were few and thin, and farm labor It is also not clear to me that we need to assume that the rules were "consciously designed."

6 "All of the following sources of institutional changes are changes in relative prices: changes in the ratio of factor prices (i.e., changes in the ratio of land to labor, labor to capital, or capital to land), changes in the cost of information, and changes in technology (including significantly and importantly, military technology). Some of these relative price changes will be exogenous ... (such as the changes in land/labor ratios that resulted from the plague in late medieval Europe); but most will be endogenous, reflecting the ongoing maximizing efforts of entrepreneurs (political, economic, and military) that will alter relative prices and in consequence induce institutional change. The process by which the entrepreneur acquires skills and knowledge is going to change relative prices by changing perceived costs of measurement and enforcement and by altering perceived costs and benefits of new bargains and contracts." (North 1990, p. 84.) 
was relatively scarcer than it had been under Rome and scarcer than it would be again in the High Middle Ages. By obligating workers to lords, serfdom ameliorated the problem of thin markets by lowering the transaction costs of directing workers to produce what the lords desired. ${ }^{7}$ Moreover, since labor was relatively more scarce than land, labor ought to have collected the majority of the economic rents. Tying the workers to the land prevented the labor market from operating - in analogy with professional sports before the era of free agency - and allowed the lords to reap what rents there were (Domar 1970). As population grew in Europe and markets developed, the rationale for serfdom evaporated, and labor became increasingly free. Notice that the institution we observe serfdom - does indeed solve an economic problem. But we cannot understand where that problem came from, and how it disappeared, without understanding both production costs and transaction costs.

The extent of the market need not always be increasing. Institutional failure can lead to a decline in the extent of the market, as it did after the fall of Rome, during the period historians used to call, with complete accuracy, the Dark Ages (Ward-Perkins 2005). The calamitous fourteenth century would be another example (Tuchman 1978). Since the beginning of what we now call the early-modern period, however, the extent of the market in Europe has been increasing on trend. As Adam Smith (1976) long ago taught us, one implication of growth in the extent of the market is that it begins to pay to switch from technologies of production and transaction with low fixed costs to those with

7 Which is a variant of Coase's (1937) theory of vertical integration (Langlois 2007, pp. 1110-1111). 
high fixed costs. ${ }^{8}$ We are familiar with this phenomenon at the level of production costs and technology, but it is also important at the level of institutions. Some institutions have low fixed costs and high variable costs; some have high fixed costs but low variable costs. As Allen himself tells us in his excellent work on the meaning of transaction costs, both the fixed and the variable costs of institutions are transaction costs, "the costs of establishing and maintaining property rights" (Allen 2000, p. 898).

Consider the following example, which also illuminates the subtle coevolution of standardization and variance with the extent of the market. In the American Midwest before the coming of the railroad, as indeed throughout much of agricultural history, wheat was stored, shipped, and traded by the sack (Cronon 1991). Each sack of wheat was the product of a specific identifiable farmer, which meant that monitoring costs were low because repeated trades would generate reputation effects that assured the quality of the grain. At the same time, however, this mode of storage meant high transportation costs of shipping the sacks by wagon and river to urban mills. All of this changed with the coming of the railroad in the mid-nineteenth century. It quickly became economical to store and ship wheat in bulk, using the newly invented mechanical grain elevator. This reduced shipping costs dramatically. ${ }^{9}$ But, as it necessitated mixing together the grain of many different farmers, it destroyed the system of quality control that had relied on reputational effects from repeated transactions with identifiable farmers. To solve this problem, the Chicago Mercantile Exchange paid the fixed set-up costs of creating

$8 \quad$ I'm being a bit fast-and-loose here about what Smith actually said. For a thorough discussion of Smith, the division of labor, and fixed costs, see (Langlois 2003a).

9 A typical large elevator of the era could simultaneously empty twelve railroad cars and load two ships at the rate of 24,000 bushels per hour (Cronon 1991, p. 113). 
standardized categories for wheat and persuading farmers and buyers to adopt those standards (Cronon 1991). In addition, the Exchange needed to confront the costs of inspecting the wheat for conformance to the standards, which they did by commissioning inspectors, whose work became a (transaction) cost of the contracts traded on the Exchange. Notice that here institutional change was driven by a change in production costs (a change in technology), not a change in variance. Notice also that standardization in this case was a result not a cause of institutional change. The dramatically lower production costs of the elevator system actually increased transaction costs, even though they far more than counterbalanced them.

To the extent that The Institutional Revolution falls short it is precisely when Allen fails to keep production costs as well as transaction costs in sight and when he fails to imbed his transaction-cost story within a larger account of institutional change. A prime example here is Allen's treatment of the transition to the factory system, a topic on which I have written (Langlois 1999). Beginning in the late Middle Ages, the British textile industry, first in woolens and later in cotton as well, operated around the puttingout system, in which vertically specialized cloth merchants outsourced spinning and weaving to rural cottagers. The cottagers were genuinely contractors not workers: they owned their own machinery and received compensation by the piece. By the late eighteenth century this system in cotton came to be challenged by the so-called factory system, in which operatives relocated to a central factory, worked with machines they did not own, and received a wage instead of a piece rate. Why? The traditional account among economic historians had always been machinery: the factory system emerges 
upon the invention of large-scale high-throughput textile machinery ${ }^{10}$ (Landes 1986; Mantoux 1961; Ure 1861).

Allen is not the first to attempt to analyze this transition by considering only transaction costs and ignoring the serious issues of production costs. In his famous radical broadside, Stephen Marglin (1974) announced that one could understand the transition to the factory system as a purely organization matter. Holding technology constant, he argued, bosses want to switch to the factory system because it enables them to break work into simple tasks and thus to "deskill" the workers, which shifts the rents of skill away from laborers and onto capitalists. (Compare the discussion of serfdom above.) Institutional economists responded to Marglin as both threat and opportunity: Marglin was wrong about exploitation, but right that one could explain the factory system by looking only at transaction costs. Williamson (1980) constructed a thought experiment in which, holding technology constant, the putting-out system appears more costly than the factory system, largely because outsourcing permitted greater “embezzlement," as pilfering of materials was called, and required larger work-in-process inventories.

The claim that transaction costs alone explain the factory system was a just-so conjecture that began a thorough and fruitful reexamination of the origins of the factory system. Economic historians jumped in to point out that, in history as it actually happened, technology did not remain constant, and in fact it was production costs not transaction costs that drove this institutional change. In the era of hand-operated

\footnotetext{
10 "The factory system ... was the necessary outcome of the use of machinery" (Mantoux 1961, p. 246).
} 
machines, production costs for the putting out system were lower by a third than for a system requiring workers to congregate in one place (Jones 1982, 1999). This was so because, among other reasons, cottagers continued to engage in agriculture, producing food from their own crofts and earning occasional income from farm labor, all of which lowered the opportunity costs of textile work. Moreover, although embezzlement did take place and cottagers had to hold inventories while waiting for their output to be collected, economic historians tend to argue that those costs were relatively low (Clark 1994; Jones 1982), especially in view of the favorable monitoring-cost properties of what was essentially a self-monitoring residual-claim system.

In work that was clearly influential on Allen, Rick Szostak (1989) rightly points to the growing extent of the market as critical for understanding the transition from the putting-out system to the factory system. Yet Szostak also chooses to tug on a thin explanatory strand, in this case a reduction in transportation costs that shifted advantage away from decentralized local production in cottages to centralized production in factories. It is far from clear why a reduction in transportation costs should favor centralization: in our own era lower transportation and transaction costs are associated with increased outsourcing. ${ }^{11}$ What is decisive for Szostak in the end is Williamson's account of transaction costs saved by concentrating workers in one place: "the advantages the factory possessed were almost entirely in terms of the opportunity provided for supervision of workers" (Szostak 1989, p. 344). With decreased transportation costs, he argues, trade was becoming increasingly anonymous, and embezzlement and lack of

11 Even though my own explanation relies on the extent of the market, not lower transaction costs arising from technological change (Langlois 2003b, 2004). 
standardization were becoming more costly. Changing technology cannot explain the transition, he tells us, because many centralized workplaces emerged in this period using exactly the same technology as the cottagers. What reason could there be for this centralization other than the desire to monitor for embezzlement, product quality, and standardization?

Were we to pull on the whole thick thread of the extent of the market, however, we would reel in a more obvious and plausible explanation. It is certainly true that, as transportation costs fell and markets expanded, it began to pay to tap labor outside of the pool of cottagers, especially labor within the developing urban areas, where earlier guild regulation had largely fallen by the wayside. But - notably in textiles - this was simply because the extent of the market was growing at a rate that was beginning to outstrip the capacity of the putting-out system. Capitalists turned to urban workshops to meet the demand. If capitalists had switched away from putting out to centralized workshops largely to reduce embezzlement, we should expect to see decline, or at least stagnation, in the putting-out system. Instead, what we see before mechanization is a growth both in urban workshops and in the putting-out system (Jones 1999, p. 40), as the expansion of the market for British textiles drove the putting-out system beyond the point of diminishing marginal returns. The result was technological and institutional change. Urban workshops were the beginning of that change; mechanization and the full-fledged factory system were a more significant response. Only with the advent of mechanization did the putting-out system begin to decline.

Operatives in workshops using the technology of the cottagers were paid like the cottagers — by the piece — making them essentially inside contractors (Buttrick 1952). 
When human power gave way to inanimate power, however, the operatives tending the machines were increasingly confronted with a wage rather than a piece-rate contract. ${ }^{12}$ Why should this be? Retaining the piece-rate system - converting outside contracting into inside contracting - would have retained the monitoring-cost benefits of a residualclaim system without impeding supervision for quality control and against embezzlement. Why switch to a system of hourly wages, which is canonically notorious for problems of moral hazard?

The answer, which Allen wrongly dismisses, is machinery. High-throughput machinery was an innovation induced in response to the encroaching limits of the putting-out system and of the piece-rate system more generally. As the economic historians tell us, the coming of inanimate power eliminated the worker's comparative advantage in owning capital (Landes 1986). Whereas to the textile capitalist the puttingout system had been a low-fixed-cost high-variable-cost system, powered machinery came with high fixed costs, and it necessitated that the capitalist not the worker pay those fixed costs. So factory owners were extremely anxious to keep the machinery constantly operating in order to spread their costs over as many units of output as possible. Because the supply curve of worker effort was backward-bending at contemporary income levels, the capitalists could not ensure high throughput simply by manipulating the piece rate. What was called for was a non-marginal institutional change: a switch to a system in which capitalist and worker could somehow strike a high-pay high-effort wage bargain.

12 Some piece rates continued even in a factory setting, as in the case of master spinners, who were effectively inside contractors who did not own their own machines (Lazonick 1990, pp. 80-85). But these master spinners were themselves employers (indeed the principal employers of child labor in the period) and they did not pay their own employees by the piece. 
To enforce the bargain and counteract shirking, the capitalists had to hire supervisors to apply factory discipline, which was far more about keeping up effort levels than it was about ferreting out embezzlement (Pollard 1963). Notice that, as in the wheat example, technological change in this case lowered production costs dramatically but actually increased transaction costs.

Adhering to a transaction-cost-only story à la Williamson and Szostak causes Allen to say, albeit in passing, some rather silly things about the factory system. The silliest of these is that, in the era of water and before steam power, capitalists repaired to the countryside in order to create "factory colonies" (Allen 2011, p. $211 \mathrm{ff}$.). This they did to eliminate the scourge of embezzlement and poor quality by keeping the workers where they could see them. Allen dismisses the obvious objection that capitalists took production to the countryside in search of water power: there was plenty of water in cities! He also dismisses the even more damaging objection that factories instantly moved to the cities once steam power became available: capitalists moved to the cities because newly created police forces could suddenly solve the problem of embezzlement at the exact moment steam engines appeared! As the historical record attests, however, capitalists did indeed move to the countryside in search of water power. ${ }^{13}$ Moreover,

13 Physics tells us that all that matters for water power is the height of the fall, and pre-existing large cities, even ones that had grown up around Roman or medieval water mills, are not likely to have had enough suitable falls. " $[\mathrm{N}] \mathrm{o}$ factory could be established far from a stream powerful and swift enough to set the machines in motion. For this reason it was not in towns that the millowners at first established their factories, but near the hills, in narrow valleys where by using dams it was easy to create an artificial waterfall. The beginnings of the modern factory system are to be found in small hamlets, far removed from those great industrial centres round which the mass of the working population has since gathered. These small places were scattered along the foot of the Pennine range, on all three sides of it; on the west towards Manchester and the Irish Sea, on the south towards the Trent valley, and on the east towards the Yorkshire plain and the North Sea" (Mantoux 1961, p. 247). One could easily multiply citations; but see especially Unwin (1924, pp. 119-123), drawn from 
they did so not to lower their variable costs but despite a significant increase in variable costs. The owners of these "colonies" had to pay a premium to uproot workers and had to provide infrastructure that ranged from housing to schools and churches ${ }^{14}$ (Chapman 1976; Pollard 1964). Many even had to integrate into farming in order to occupy the male family members of the workers as well as to provide food for the colony (Pollard 1964, pp. 515-516). All this the mill owners did willingly because the dramatically lower costs of machine production - not the relatively minor benefits of reduced embezzlement - offset the high cost of labor. Mills powered by steam sprang up in cities not in the country because cities offered more-abundant labor and a thicker market for complements that could provide housing and other amenities more cheaply (Chapman 1976, p. 135).

Allen's discussion of the factory system is little more than an aside in The Institutional Revolution. But it seems to me that the central core of the book - the analysis of early-modern aristocracy - would benefit greatly if it too were more firmly tied together with some thicker explanatory thread. Indeed, Allen's analysis fits well within the narrative of what North, Wallis, and Weingast (2009) have called the natural state.

primary sources, which also points out that the demand for rural falls led to rapid and dramatic change in water-rights law.

14 Allen contends that the peculiar forms of paternalism of the "factory colonies" shows that their raison d'être was monitoring for embezzlement and standardization. In fact, even in a world with no embezzlement, such paternalism would be perfectly consistent with the need to attract, retain, and train costly workers in a remote location with thin markets. Indeed, owners like Oldknow generally resorted to long-term contracts and indenture (Chapman 1967, p. 137) - contractual features consistent with a desire to eliminate worker mobility (cf. serfdom once again) but inexplicable in an embezzlement story. 
In a Hobbesian state of nature, the constant threat of expropriation limits economic activity. To the extent that some economic agents succeed in producing output above subsistence, others will try to seize the proceeds. But this sorry situation creates a profit opportunity: as we saw in the case of the early Middle Ages, it may pay for some agents to specialize in violence and to offer their services to productive agents in exchange for some large share of the increased output this arrangement permits (North 1981). As Mancur Olson (1993) famously put it, the roving bandits of itinerant warlordism settled down to become the sedentary bandits of feudalism. But, as North, Wallis, and Weingast (2009) point out, a relatively complex division of labor cannot flourish in a world of many small independent sedentary bandits. Relatively complex economic organization can emerge only to the extent that there arises among competing bandits agreement to refrain from violence, thereby increasing the extent of the market and allowing the bandits to share the fruits of the productive economic activity their forbearance would permit.

Such an agreement, or coalition, is what North, Wallis, and Weingast call the natural state.

The natural state reduces the problem of endemic violence through the formation of a dominant coalition whose members possess special privileges. The logic of the natural state follows from how it solves the problem of violence. Elites - members of the dominant coalition - agree to respect each other's privileges, including property rights and access to resources and activities. By limiting access to these privileges to members of the dominant coalition, elites create credible incentives to cooperate rather than fight among themselves. Because elites know that violence will reduce their own rents, they have incentives not to fight. Furthermore, each elite understands that other elites face similar incentives. In this way, the political system of a natural state manipulates the economic system to produce rents that then secure political order. (North, Wallis and Weingast 2009, p. 18.) 
Notice that this account provides an explanation for the behavior of the aristocracy that is consistent with, but richer than, that of Allen. The aristocracy of early-modern Britain is the elite of a developing natural state. From this perspective, puzzling hostage investments and related aristocratic behavior are as much about maintaining a rentcreating and rent-sharing coalition as they are about providing public services effectively. Allen's variance story fits within the natural-state account, and remains important for explaining details of the organization of the military and of public services. Arguably, however, the natural-state analysis displaces variance as the principal explanation for the institution of early-modern European aristocracy.

One source of critical reflection on our just-so stories is cross-country or historical comparison. As I read The Institutional Revolution, I continually found myself considering the comparison with China. At a time well before the early-modern period in Europe, Imperial China ran on a system of bureaucracy and even meritocracy - despite the fact that their technology, including technology of communication, transportation, and measurement, was essentially the same as or inferior to that of Europe in Allen's period. Although the Chinese system was not without elements of a patron-client network, in China it was famously a set of exams - not primarily one's connections, let alone a duel - that secured entry into the public-service elite. ${ }^{15}$ And the system of monitoring was clearly bureaucracy, of a sort that strikes us as extremely modern. If variance were the only issue, why could China run this way while Europe couldn't?

15 Studying for these exams took years, which was clearly a major investment in human - and probably hostage - capital. But the skills one learned in the Chinese process were much more highly correlated with the tasks of the bureaucracy and public service than were the skills European aristocrats invested in. 
Through the lens of the natural-state argument, we see immediately that China had less need for loyalty and hostage investments because its elite coalition was more stable and centralized. The reasons behind centralization and stability are probably in part a matter of history and geography, but they also have to do with the agricultural structure of rent extraction. Indeed, as Allen himself notes, the distinctive behavior of aristocrats was typically less pronounced on the European continent than in Britain (Allen 2011, p. 74). I conjecture that this difference arises from the same source: compared to, say, prerevolutionary France, Britain in the early-modern period was debating and experimenting with a new model of rent-extraction dependent less on agriculture and more on trade and commerce (Pincus 2009, chapter 12). The resulting stresses called for far more severe measures to keep the coalition together than were necessary in France, let alone in China. $^{16}$

I may appear to end here on a note of criticism. But I view all that I have said not only as criticism of the friendly variety but also as a kind of criticism that tries to embellish and enrich - not to tear down - the project Allen has embarked upon. It is through such criticism and revision that our just-so stories transform and mature into persuasive sagas.

As Allen (2011, pp. 101-103) also notes, Oliver Cromwell had moved to a somewhat more meritocratic system during the Republic. This ultimately failed not because variance made it unworkable but because the narrowness of Cromwell's (largely religion-driven) patron-client network made the larger elite coalition unstable, leading to the Restoration and eventually a sort of equilibrium after the Glorious Revolution. 


\section{References.}

Allen, Douglas W. 2000. "Transaction Costs," in Boudewijn Bouckaert and Gerrit De Geest, eds., The Encyclopedia of Law and Economics. Cheltenham: Edward Elgar, pp. 893-926.

Allen, Douglas W. 2011. The Institutional Revolution. Chicago: University of Chicago Press.

Brewer, John. 1988. The Sinews of Power: War, Money, and the English State, 1699-1783. Cambridge: Harvard University Press.

Buttrick, John. 1952. "The inside Contract System," The Journal of Economic History 12(3): 205-221.

Chapman, S. D. 1967. The Early Factory Masters: The Transition to the Factory System in the Midlands Textile Industry. Newton Abbot: David \& Charles.

Chapman, S. D. 1976. "Workers' Housing in the Cotton Factory Colonies, 1770-1850," Textile History 7(1): 112-139.

Clark, Gregory. 1994. "Factory Discipline," The Journal of Economic History 54(1): 128-163.

Coase, Ronald H. 1937. "The Nature of the Firm," Economica (N.S.) 4: 386405.

Coase, Ronald H. 1960. "The Problem of Social Cost," Journal of Law and Economics 3: 1-44.

Cronon, William. 1991. Nature's Metropolis: Chicago and the Great West. New York: W. W. Norton. 
Demsetz, Harold. 1969. "Information and Efficiency: Another Viewpoint," Journal of Law and Economics 12(1): 1-22.

Domar, Evsey D. 1970. "The Causes of Slavery or Serfdom: A Hypothesis," The Journal of Economic History 30(1): 18-32.

Greif, Avner. 2002. "Institutions and Impersonal Exchange: From Communal to Individual Responsibility," Journal of Institutional and Theoretical Economics 158: 168-204.

Greif, Avner. 2006. Institutions and the Path to the Modern Economy: Lessons from Medieval Trade. New York: Cambridge University Press.

Johnson, Ronald and Gary Libecap. 1994. "Patronage to Merit and Control of the Federal Government Labor Force," Explorations in Economic History 31(1): 91-119.

Jones, S. R. H. . 1982. "The Organization of Work," Journal of Economic Behavior and Organization 3(2): 117-137.

Jones, S. R. H. . 1999. "The Origins of the Factory System in Great Britain: Technology, Transaction Costs, or Exploitation?," in Paul L. Robertson, ed., Aiuthority and Control in Modern Industry. London: Routledge, pp. 17-44.

Landa, Janet T. 1994. Trust, Ethnicity, and Identity: The New Institutional Economics of Ethnic Trading Networks, Contract Law, and GiftExchange. Ann Arbor: University of Michigan Press.

Landes, David S. 1986. "What Do Bosses Really Do?," The Journal of Economic History 46(3): 585-623. 
Langlois, Richard N. 1986. "Rationality, Institutions, and Explanation," in Richard N. Langlois, ed., Economics as a Process: Essays in the New Institutional Economics. New York: Cambridge University Press, pp. 225-55.

Langlois, Richard N. 1999. "The Coevolution of Technology and Organization in the Transition to the Factory System," in Paul L. Robertson, ed., Authority and Control in Modern Industry. London: Routledge, pp. 45-72.

Langlois, Richard N. 2003a. "Cognitive Comparative Advantage and the Organization of Work: Lessons from Herbert Simon's Vision of the Future," Journal of Economic Psychology 24(2): 167-187 (Apr).

Langlois, Richard N. 2003b. "The Vanishing Hand: The Changing Dynamics of Industrial Capitalism," Industrial and Corporate Change 12(2): 351-385 (April).

Langlois, Richard N. 2004. "Chandler in a Larger Frame: Markets, Transaction Costs, and Organizational Form in History," Enterprise \& Society 5(3): 355-375 (September).

Langlois, Richard N. 2007. "The Entrepreneurial Theory of the Firm and the Theory of the Entrepreneurial Firm," Journal of Management Studies 44(7): 1107-1124 (November).

Lazonick, William. 1990. Competitive Advantage on the Shop Floor. Cambridge: Harvard University Press.

Mantoux, Paul. 1961. The Industrial Revolution in the Eighteenth Century. London: Jonathan Cape. 
Marglin, Stephen A. . 1974. "What Do Bosses Do?," Review of Radical Political Economy 6: 33-60.

Miceli, Thomas J. and Kathleen Segerson. 2007. "Punishing the Innocent Along with the Guilty: The Economics of Individual Versus Group Punishment," The Journal of Legal Studies 36(1): 81-106.

Miller, Nolan H., Alexander F. Wagner and Richard J. Zeckhauser. 2013. "Solomonic Separation: Risk Decisions as Productivity Indicators". NBER Working Paper 18634.

North, Douglass C. 1981. Structure and Change in Economic History. New York: Norton.

North, Douglass C. 1990. Institutions, Institutional Change and Economic Performance. New York: Cambridge University Press.

North, Douglass C. 2005. Understanding the Process of Economic Change. Princeton: Princeton University Press.

North, Douglass C., John Joseph Wallis and Barry R. Weingast. 2009. Violence and Social Orders: A Conceptual Framework for Interpreting Recorded Human History. New York: Cambridge University Press.

Olson, Mancur. 1993. "Dictatorship, Democracy, and Development," The American Political Science Review 87(3): 567-576.

Pincus, Steve. 2009. 1688: The First Modern Revolution. New Haven: Yale University Press. 
Pollard, Sidney. 1963. "Factory Discipline in the Industrial Revolution," Economic History Review 16: 254-271 (December).

Pollard, Sidney. 1964. "The Factory Village in the Industrial Revolution," The English Historical Review 79(312): 513-531.

Ruttan, Vernon W. and Yujiro Hayami. 1984. "Toward a Theory of Induced Institutional Change," The Journal of Development Studies 20(4): 203-223.

Smith, Adam. 1976. An Enquiry into the Nature and Causes of the Wealth of Nations. Oxford: Clarendon Press.

Szostak, Rick. 1989. "The Organization of Work: The Emergence of the Factory Revisited," Journal of Economic Behavior \& Organization 11(3): 343-358.

Tuchman, Barbara. 1978. A Distant Mirror: The Calamitous Fourteenth Century. New York: Knopf.

Unwin, George. 1924. Samuel Oldknow and the Arkwrights: The Industrial Revolution at Stockport and Marple. Manchester: Manchester University Press.

Ure, Andrew. 1861. The Philosphy of Manufactures. London: G. H. Bohn.

Ward-Perkins, Bryan. 2005. The Fall of Rome: And the End of Civilization. Oxford: Oxford University Press.

Williamson, Oliver E. 1980. "The Organization of Work: A Comparative Institutional Assessment," Journal of Economic Behavior and Organization 1(1): 5-38. 
Williamson, Oliver E. 1985. The Economic Institutions of Capitalism. New York: The Free Press.

Williamson, Oliver E. 1991. "Comparative Economic Organization: The Analysis of Discrete Structural Alternatives," Administrative Science Quarterly 36(2): 269-296. 